\title{
Cash Flow Management and Industrial Firms Performance in Nigeria
}

\author{
Idamoyibo Hwerien Rosemary ${ }^{1}$, Abner Ishaku Prince ${ }^{2}$, Akpan Ededem Jack ${ }^{3}$, \\ Orugun Ibidunni Fausat ${ }^{4}$, Emmanuel Nwabueze Enoch $^{3}$, Udo Emmanuel Samuel ${ }^{3, *}$ \\ ${ }^{1}$ Department of Accounting, Ignatius Ajuru University of Education, Port Harcourt, Nigeria \\ ${ }^{2}$ Department of Management, University of Nigeria Enugu Campus, Nigeria \\ ${ }^{3}$ Department of Banking and Finance, University of Nigeria Enugu Campus, Nigeria \\ ${ }^{4}$ Department of Banking and Finance, Kogi State University, Nigeria
}

Received March 9, 2021; Revised June 22, 2021; Accepted July 19, 2021

\section{Cite This Paper in the following Citation Styles}

(a): [1] Idamoyibo Hwerien Rosemary, Abner Ishaku Prince, Akpan Ededem Jack, Orugun Ibidunni Fausat, Emmanuel Nwabueze Enoch, Udo Emmanuel Samuel , "Cash Flow Management and Industrial Firms Performance in Nigeria," Universal Journal of Accounting and Finance, Vol. 9, No. 4, pp. 701 - 711, 2021. DOI: 10.13189/ujaf.2021.090416.

(b): Idamoyibo Hwerien Rosemary, Abner Ishaku Prince, Akpan Ededem Jack, Orugun Ibidunni Fausat, Emmanuel Nwabueze Enoch, Udo Emmanuel Samuel (2021). Cash Flow Management and Industrial Firms Performance in Nigeria. Universal Journal of Accounting and Finance, 9(4), 701 - 711. DOI: 10.13189/ujaf.2021.090416.

Copyright $\odot 2021$ by authors, all rights reserved. Authors agree that this article remains permanently open access under the terms of the Creative Commons Attribution License 4.0 International License

\begin{abstract}
The focal point of this research was to establish the liquidity-viability link in quoted non-financial firms in Nigeria. Liquidity improves the profitability of firms but not its solvency. The solvency and performance of a firm exclusively anchor on the firm's capacity to realize the "twin conflicting" targets of liquidity sufficiency and stable growth through a diversified and stable asset-liability mix. The firm's inability to strike an equilibrium balance among meeting financial obligations, sufficient liquidity and profitability has led to insolvency of most firms in Nigeria. Most empirical studies in Nigeria ignore effect of cash flow management on the non-financial sector to focus on the financial sector. Use the regression model predominantly and also ignore the widely accepted econometric process of a pre and post diagnostic test. This study focuses on 13 quoted non-financial sectors in Nigeria firms from 1999-2020. The preliminary test was conducted to determine the best fit model. Liquidity proxy by the current ratio significantly influences ROE and non-significantly on ROE when proxy by the cash flow ratio. Findings also divulged a bidirectional nexus between current ratio, cash flow ratio, and ROE and a non-causal nexus with other variables. Policy recommendations are further discussed.
\end{abstract}

Keywords Cash Liquidity, Management Financial Performance, Non-financial Firms, Nigeria

JEL Codes: A12, M21, C0, G32, G02.

\section{Introduction}

Industrial sector proficiency is vital to the stability of any nation's economy. Instability caused by both industrial and non-industrial factors of Covid-19 pandemics among others have far-reaching implications on the overall economy. The growth of the industrial sector dependent absolutely on resourceful liquidity management. The influence of liquidity on firm's financial performance cannot be underrated. Liquidity and cash are used interchangeably in this analysis. Liquidity is a critical component of the fulcrum that determines the firm financial performance [1]. Cash flow sufficiency guarantees firms' immediate fulfillment of its financial obligations without evasion [2].

It represents the firm's vascular system, a unit decrease jeopardises the firm survival. Liquidity measures a firms' financial strength to fulfill its immediate financial obligation upon its maturity, through short-term assets conversion into cash at a minimal loss $[3,4]$.

Firms with equilibrium balance between cash flow and liquidity are considered by investors, customers, and creditors viable for investment and planning. The value of an asset is measured by its liquidity value, when converted at little or no loss of value $[2,4,5]$. Liquid asset improves the profitability of firms but not its solvency. Firms 
liquidity management encompasses some intense trade-offs between risks and return linked to short-term asset and liabilities management. It is considered a crucial financial management process and as a measure of working capital and cash conversion cycle.

The firm's ability to realize the "twin conflicting" targets of adequate liquidity/stable financial performance through a diversified and stable asset-liability mix influences its solvency.

The flexibility, solvency and ability to strike an equilibrium balance between meeting its financial obligations, retaining its competitive prowess, and remaining profitable are set on the firm's ability to generate net positive cash flows from the operating, investing and financing activities [3,2].

Net positive cash flow signifies prudent conservative cash control under a firm operational and business objective of financing, operating, and investing [5]. Inputs and outputs liquidities and cash equivalents embody cash flows. Cash on hand and demand deposits signify liquidities. Cash flow are direct measures of liquidity and contributing factors to corporate financial growth of firms.

The tradeoff theory, postulate that the optimal cash level of a firm is maintained at the breakeven point where the marginal cost and benefit of holding cash are equal. The benefits of holding cash are derived from two vital motives: Precautionary and transaction motive.

Sufficient cash outflow out-weighting inflow signifies weak liquidity control, debt, bad inventory, feeble investment skills, and financial managers' incompetence to critically engage in optimal financing decisions. Resourceful management of cash flow, short-term assets and equivalent payables is a question of life and death for firms and has much to do with its sustained corporate existence.

The primary objective of firms away from consumers satisfaction is the determination of the best possible way to sustain and improve its profitability and competitive prowess. Thus, there is a dare need for critical evaluation and monitoring of those factors that affect firm's profitability. Liquidity and cash flow management are one of the numerous financial, managerial and non-financial and managerial that cannot be ignored given its implications on corporate risk and returns.

Empirical findings from studies in Nigeria indicate that most quoted firms in Nigeria faced the ultimate task of equitable management of cash resources to improve their production and liquidity prowess. This is evidence in the delisting of various firms such as the African Paints (Nigeria) PLC, MTI PLC, UTC PLC, Nigerian Ropes Plc, West African Glass Industries PLC, Alumaco PLC, West African Aluminum PLC, Nigeria Wire Industries PLC, OLUWA Company PLC among others by the regulators, as a result of unrectified anomalies of which low liquidity is central. The Nigerian Ropes Plc, West African Glass Industries PLC, Alumaco PLC, West African Aluminum PLC, Nigeria Wire Industries PLC were all legally suspended from the stock market before their delisting.

The exclusion of these firms by regulators from the stock market for various reasons lend credence to the objective of this paper, which is to investigate cash flow management and financial performance of non-financial quoted firms in Nigeria.

Prior studies on cash flow focus on the industrial and non-industrial quoted firms in emerging and industrialized economies. The findings of this study revealed diverse results; [6] in Kenya [7] in Ghana [58] in Morocco and [59] in Nigeria reported a positive nexus. [8] in Sri Lanka telecommunication sector reported a diverse result among quoted firms on cash position and profitability. [9] in Pakistani also reported a negative result. In Nigeria, a positive nexus was observed among quoted firms in the food and beverage firms, financial institutions, and the energy sector by $[10,11,12,60]$ on cash flow and performance nexus.

The diverse result reported among most of the prior studies can be accredited to firm-specific factors, the model of analysis, the technique of data collection, variables of measurement, and the techniques of cash management among others. Owing to the fast-evolving business and economic climate, increased competition among firms in Nigeria and globally. There is a dare need for firms to retained and remined competitive through efforts to enhance their growth and profitability. This research paper employs contemporary econometric technique (panel data analysis) to extend frontiers and improve on the other empirical studies in Nigeria.

The panel data methodology was adopted as it allows for an unbiased and efficient estimation. The research findings will aid financial managers in the studied sector to divulge apt liquidity management tactics for their firms' inclusive value. It will also aid in framing key strategies and programs to stir the sustainability of the industrial firms. And also assist Securities and Exchange Commission (SEC), other regulatory and supervisory bodies to advance their framework of supervision and regulations. The findings will also benefit scholars as it contributes to the extant literature on cash flow-firm performance nexus. The study also contributes to the global knowledge bank as it evaluates cash flow-financial performance nexus in the industrial firms in Nigeria. Which most prior studies ignored to focus on the financial sector. Most of these studies using panel data ignore the extensively recognized econometric process of a pre-test for dependencies or independencies to determine the best fit method of estimation. The study contributes by going through the laid down econometric processes to ensure the best fit model is determined for a meaningful analysis. The aforementioned contributions are novel as they are scarce in most studies conducted within the Nigerian academic research climate.

\section{Literature Review}

A firm's performance prowess is sizably affected by various factors and cash flow management is key among them. Numerous theoretical, and empirical studies conducted to explore possible "positive, negative, or no 
nexus" among the quantum of a firm cash management techniques and performance index revealed mixed results and findings. Insolvency is a function of insufficient liquidity, notwithstanding the asset's sufficiency to manage liabilities. According to $[13,14,15]$ the firms' ability to finance their short-term obligations conveniently shows their liquidity prowess. The asset quality of the firm is measured by its ease of conversion into liquid assets [16, $17,14,15]$. The liquidity-financial performance tie has several theoretical underpinnings. Hence, the adoption of the trade-off theory and the Cash Conversion Cycle (CCC) theories to examine the cause-effect nexus in Nigeria.

\section{The Trade-Off-Theory}

The trade-off theory postulates that to maximizes shareholders' wealth, a firm must maintain an ideal liquidity level at the breakeven point where the marginal cost and benefit of cash handling are equal. According to [18] a firm's cash liquidity position and profitability status are two economic expressions with unidirectional movement to one point inevitably implying a departure from the other. By implication liquidity and profitability are diametrically opposing ends, the pursue of one will entail a trade-off of the other. [2] argued that a firm can target liquidity and profitability due to their unwavering linkage. The equilibrium trade-off stance puts a firm in a position where it is both liquid and viable.

The liquidity trade-off hypothesis, suggests that a firm must aim for an ideal level of liquidity to create cost and benefits of handling cash symmetry. The opportunity cost characterized by low liquidity return can be accredited to liquidity premium and possible tax obligations as a cost element of handling cash. The advantages include acting as a buffer against unexpected losses, minimising the costs of obtaining external capital, and lessening the risk tie nexus with selling the firms' assets to sustain investment policy in the case of a financial crisis.

Aside from the pros of dealing with cash, there are several cons allied with it as well. Cash handling, according to [19] increases agency cost. Firms with higher leverage incur high costs in meeting their obligation and are not required to seek financing from the capital due to the impact on their financial viability. To maintain a balance liquid-profitability nexus, an appropriate level of liquid resources is required.

\section{The Cash Conversion Cycle (CCC)}

Richards and Laughlin (1980) proposed the CCC measure, herein referred to as the Cash-to-Cash Cycle. The $\mathrm{CCC}$ is based on three cash flow variables that determine a firm's cash position [20]. The CCC calculated as: Days of Sales Outstanding + Days of Inventory Outstanding - Days of Payables Outstanding.

The days of sales outstanding and days of inventory outstanding correlates with the firm's cash inflow "inventory and account receivables consider as short-term assets and positive figures" while days of payables outstanding correlates with the firm's cash outflow "accounts payable consider as liability" and a negative figure in the calculation.

The theory is based on networking capital that captures both current assets and current liabilities. The Current Ratio (CR) and its associates are most commonly adopted in measuring a firms' liquidity according to [21].

These measures ignore the time element. The incorporation of $\mathrm{CCC}$ to traditional indicators leads to more thorough scrutiny of the firm's liquidity status [21].

Other tactics of liquidity that rely on the segregation of working capital are considered inferior to CCC theory [20]. There are extensive empirical studies on cash liquidity management and firms' financial performance. The results are, however, contradictory as in (Table 1) below. 
Table 1. Summary of Empirical Review

\begin{tabular}{|c|c|c|c|c|}
\hline Authors & Objective & Scope & Methodology & Findings \\
\hline$[22]$ & $\begin{array}{l}\text { liquidity and agricultural firms' } \\
\text { performance }\end{array}$ & Kenya & Pooled & Positive impact $(+)$ \\
\hline [23] & liquidity and firms' performance & $\begin{array}{l}23 \text { quoted industrial firms } \\
\text { in Jordan }\end{array}$ & Regression & Positive impact $(+)$ \\
\hline [24] & Liquidity and firms' performance & $\begin{array}{l}39 \text { quoted non-financial } \\
\text { firms in Kenya }\end{array}$ & $\begin{array}{l}\text { Multivariate } \\
\text { regression }\end{array}$ & Positive impact $(+)$ \\
\hline [25] & Liquidity and firms' performance & $\begin{array}{l}\text { Industrial and service } \\
\text { sector firms in Jordan }\end{array}$ & Regression & Positive impact $(+)$ \\
\hline [26] & Liquidity and firms' viability. & $\begin{array}{l}\text { Manufacturing in } \\
\text { Kenya. 2008-2015 }\end{array}$ & Correlational analysis & Positive impact $(+)$ \\
\hline [27] & Liquidity and firms' viability. & $\begin{array}{c}\text { Listed firms on Ghana } \\
\text { Alternative Market (GAX). }\end{array}$ & Regression & A non-significant impact \\
\hline$[28]$ & Liquidity and firms' performance & Kenya 2010 to 2014 & Regression & A non-significant impact \\
\hline [29] & Liquidity and firms' performance & $\begin{array}{l}100 \text { listed Joint Stock } \\
\text { Companies (JSC) from six } \\
\text { major sectors in the } \\
\text { Mongolian economy }\end{array}$ & Panel regression & A non-significant impact \\
\hline$[30]$ & Liquidity and firms' performance & $\begin{array}{l}\text { Sugar mills in Punjab both } \\
\text { co-operative and private } \\
2003-2004 \text { to 2013-2014 }\end{array}$ & $\begin{array}{l}\text { Multivariate } \\
\text { Regression }\end{array}$ & A non-significant impact \\
\hline [31] & $\begin{array}{c}\text { Operating Cash Flow and Current } \\
\text { ratio on the Profitability of } \\
\text { Construction firms }\end{array}$ & $\begin{array}{l}\text { Construction companies in } \\
\text { western Romania }\end{array}$ & OLS regression & A non-significant impact \\
\hline [32] & $\begin{array}{l}\text { Cash Management and Financial } \\
\text { Performance }\end{array}$ & $\begin{array}{c}\text { Northern Uganda a Case of } \\
\text { Lira District }\end{array}$ & OLS regression & A non-significant impact \\
\hline [33] & $\begin{array}{l}\text { Liquidity and viability of five } \\
\text { listed pharmaceutical firms' }\end{array}$ & Nigeria. & OLS regression & Positive impact $(+)$ \\
\hline [34] & $\begin{array}{c}\text { Cash flow and financial } \\
\text { performance }\end{array}$ & listed banks & $\begin{array}{l}\text { correlation and } \\
\text { regression }\end{array}$ & Positive impact $(+)$ \\
\hline$[35]$ & $\begin{array}{l}\text { Cash Management and } \\
\text { Performance }\end{array}$ & $\begin{array}{l}\text { Listed Firms } \\
\text { in Nigeria }\end{array}$ & $\begin{array}{l}\text { correlation matrix, and } \\
\text { Pool Ordinary Least } \\
\text { Square Regression } \\
\end{array}$ & Negative impact (-) \\
\hline \multicolumn{5}{|c|}{ Causal Relationship Between Liquidity and Financial Performance } \\
\hline [36] & Firms' value and stock liquidity & India & $\begin{array}{l}\text { ARDL and Granger } \\
\text { causality }\end{array}$ & A direct causality \\
\hline [37] & $\begin{array}{l}\text { Liquidity and } \\
\text { firms' financial performance. }\end{array}$ & Nigeria & $\begin{array}{l}\text { OLS, co-integration } \\
\text { test, and the } \\
\text { Granger causality } \\
\end{array}$ & $\begin{array}{l}\text { Mix result of a long-run } \\
\text { relationship and no acausal. }\end{array}$ \\
\hline [38] & $\begin{array}{l}\text { Liquidity and } \\
\text { firms' financial performance. }\end{array}$ & $\begin{array}{l}42 \text { establishments in Kenya } \\
\text { for the period 2012-2016 }\end{array}$ & $\begin{array}{c}\text { Granger causality and } \\
\text { linear regression } \\
\text { technique }\end{array}$ & $\begin{array}{c}\text { Mix results } \\
\text { A non-insignificant negative } \\
\text { impact and no causal } \\
\text { relationship. } \\
\end{array}$ \\
\hline [39] & Liquidity and profitability & $\begin{array}{l}5 \text { institutions in the United } \\
\text { Kingdom }\end{array}$ & Granger causality & $\begin{array}{c}\text { Mix results } \\
\text { Liquidity and profitability } \\
\text { co-integrated in the long run } \\
\text { and no causal }\end{array}$ \\
\hline [40] & Liquidity and profitability & $\begin{array}{l}40 \text { listed firms on the } \\
\text { Dhaka Stock Exchange } \\
\text { (DSE) for the period 1998- } \\
\quad 2013\end{array}$ & Granger causality & $\begin{array}{c}\text { A bidirectional causality } \\
\text { between liquidity and firms' } \\
\text { profitability measured by } \\
\text { ROA. Feedback causality } \\
\text { between firm size and } \\
\text { profitability and } \\
\text { unidirectional causality from } \\
\text { profitability to capital } \\
\text { structure in the short run. }\end{array}$ \\
\hline
\end{tabular}

Sources: Authors (2021)

The following hypotheses are formulated for testing based on reviews of the extant literature on the cash flow liquidityfirms' financial performance nexus in the industrial sector:

Hypothesis 1: There is no relationship between cash liquidity and firms' financial performance in the industrial sector in Nigeria.

Hypothesis 2: There is no causal relationship between cash liquidity and firms' financial performance in the industrial sector in Nigeria. 


\section{Methodology}

The population of this study consists of 102 listed industrial firms in the Nigerian Stock Exchange (NSE) as of December 2020. Data was gathered from the annual reports of studied firms covering 21 years (1999-2020) of 12 listed firms; of Industrial goods (Berger paints Plc, Meyer Plc, Beta Glass \& Lafarge Africa Plc) Consumer Goods (Vita foam, Nestle Nigeria Plc, Flour Mills Nig. Plc \& Honey Well), and Health Care (Ekocorp PLC, Morison Industries Plc, Neimeth International Pharmaceuticals Plc \& Nigeria-German Chemicals).

Various factors were considered in the selection process of the sample firms such as firms that were listed in NSE before the year of inception of the study, firms that ceased operation at any point during the period of the study, and those that had problems with NSE and SEC within the period under review were also excluded.

Table 2. Model Formulation

\begin{tabular}{|c|c|c|}
\hline Variables & Proxy & Measurements \\
\hline $\begin{array}{c}\text { Return on Equity } \\
\text { (ROE) }\end{array}$ & $\begin{array}{c}\text { Financial } \\
\text { performance }\end{array}$ & Net income / total equity \\
\hline $\begin{array}{c}\text { Current Ratio } \\
\text { (CRA) }\end{array}$ & Liquidity & $\begin{array}{c}\text { Total current assets / total } \\
\text { current liabilities }\end{array}$ \\
\hline $\begin{array}{c}\text { Cash Flow Ratio } \\
\text { (CFR) }\end{array}$ & Liquidity & $\begin{array}{c}\text { Net cash flows / total } \\
\text { current liabilities }\end{array}$ \\
\hline Size (SIZE) & Control variable & Natural log of total assets \\
\hline Efficiency (EFF) & Control variable & $\begin{array}{c}\text { Gross revenue / total } \\
\text { assets }\end{array}$ \\
\hline Tangibility (TAN) & Control variable & $\begin{array}{c}\text { Total tangible assets / } \\
\text { total assets }\end{array}$ \\
\hline
\end{tabular}

Sources: Authors (2021)

To examine the firms' performance and cash liquidity management nexus. Liquidity is surrogated by (Current Ratio (CRA) and Cash Flow Ratio (CFR). Performance is surrogated by ROE (see Table 2 above). ROE is adopted for its flexibility in application, it is a non-asset dependent, and can be applied to any line of business or product. The flexibility of the ROE allows for the comparison of firms with different asset structures. The asset-independency of ROE also allows for internal product line performance comparison among firms. This impossible to achieve with ROA as a performance measure. Econometric equation model:

$$
\begin{array}{r}
\mathrm{ROE}_{\text {it }}=\alpha_{\mathrm{i}}+\beta_{1} \mathrm{X}_{\mathrm{it}}+\beta_{2} \mathrm{X}_{\mathrm{it}}+\beta_{3} \mathrm{X}_{\mathrm{it}}+\beta_{4} \mathrm{X}_{\mathrm{it}}+\beta_{5} \mathrm{X}_{\mathrm{it}}+\mu \\
(\mathrm{eq} 1) \\
\mathrm{ROE}_{\mathrm{it}}=\alpha_{\mathrm{i}}+\beta_{1} \mathrm{CR}_{\mathrm{it}}+\beta_{2} \mathrm{CFR}_{\mathrm{it}}+\beta_{3} \mathrm{SIZE}_{\mathrm{it}}+\beta_{4} \mathrm{EFF}_{\mathrm{it}}+ \\
\beta_{5} \mathrm{TAN}_{\mathrm{it}}+\mu
\end{array}
$$

Where: $\mathrm{ROE}=$ Dependent Variables

$\alpha_{i}=$ Intercept of the Equation)

$\beta_{1-5}=$ Coefficient of Xit Variable capture the

$\mathrm{Xit}=$ Independent Variable $(\mathrm{CR}, \mathrm{CFR}, \mathrm{Size}, \mathrm{EFF}$, and TAN)

$\mathrm{I}=($ Cross-Sectional Variables $)$ Number of Industrial Firms

$\mathrm{t}=$ Time Period and

$\mu=$ Error terms
Where $\left(\alpha_{\mathrm{i}}\right)$ is constant over the period (eq1) can be estimated as a fixed-effects model. Also, where $\left(\alpha_{\mathrm{i}}\right)$ changes over the period and follows a definite distribution, (eq1) can be estimated as a random-effects model. To address and reduce the issues of heteroscedasticity and data fluctuations, natural logarithms were applied to the variables.

\section{Transform Model}

$$
\begin{array}{r}
\operatorname{InROE}_{\text {it }}=\alpha_{i}+\operatorname{In} \beta_{1} \mathrm{CR}_{\text {it }}+\operatorname{In} \beta_{2} \mathrm{CFR}_{\text {it }}+\operatorname{In} \beta_{3} \mathrm{SIZE}_{\text {it }}+ \\
\operatorname{In} \beta_{4} \mathrm{EFF}_{\mathrm{it}}+\operatorname{In} \beta_{5} \mathrm{TAN}_{\mathrm{it}}+\mu
\end{array}
$$

\section{Priori Test expectation}

The cash liquidity, firm size, firm efficiency, and tangibility are projected to positively influence firm performance

$$
(\beta 1>0, \beta 2>0, \beta 3>0, \beta 4>0, \beta 5>0, \beta 6>0)
$$

\section{Econometric Approach}

It's critical to determine whether the datasets have cross-sectional dependency before proceeding with the estimation. The presence of cross-sectional dependency or independence will aid in the selection of the appropriate tests of stationarity and co-integrating nexus. The cross-sectional reliance test was used based on [41] framework. This test anchor on the standard panel data model expressed as:

$$
\varepsilon_{\text {it }}=\rho_{\mathrm{i}} \varepsilon_{\mathrm{it}-1}+\mu_{\mathrm{it}}
$$

The alternative hypothesis includes the homogeneous hypothesis for individual series for the within-dimension test $\left(\mathrm{H}_{A}: \rho:=\rho<1\right)$ and heterogeneous alternative for individual series for between dimension test $\left(\mathrm{H}_{A}\right.$ : $\rho:=\rho<1)$.

The panel co-integration was adopted following the Kao (1999) framework. Panel co-integration test largely depends on the ADF statistic for which the error terms are obtained by using the regression model.

$$
y_{i, t}=\alpha_{i}+\beta_{i, t X i, t}+\mu_{i, t}
$$

\section{Unit Root Test}

The second-generation unit test for its efficiency in cross-sectional dependencies against the first-generation unit root tests that apply to cross-sectional individuality was employed.

\section{Co-Integration Test}

The [41] and the [42] framework for the co-integration test was adopted in this study to test the cross-sectional independence individual effects. The Pedroni panel co-integration test is built on the regression model expressed as:

$$
y_{i t}=\alpha_{\mathrm{i}}+\delta_{\mathrm{it}}+\beta_{1 \mathrm{iX1i, \textrm {t }}+}+\beta_{2 \mathrm{iX} 2 \mathrm{i}, \mathrm{t}}+\beta_{3 \mathrm{iXXi \textrm {t }}}+\beta_{4 \mathrm{iX} 4 \mathrm{i}, \mathrm{t}}+\beta_{5 \mathrm{iX5i,t}}+
$$


where $\alpha i$ and $\beta i j=$ intercepts, and slope of the coefficients that can vary across cross-sections, $t=1, \ldots, T, i=1, \ldots, N$, $m=1, \ldots, M ; x$ and $y=$ assumed to be integrated of the same order I(1).

The null hypothesis of no co-integration of the Pedroni panel co-integration test is determined with respect to the error term $\left(\varepsilon_{i t}\right)$. The alternative hypothesis includes the homogeneous hypothesis for individual series for the within-dimension test $\left(\mathrm{H}_{A}: \rho:=\rho<1\right)$ and heterogeneous alternative for individual series for between dimension test $\left(\mathrm{H}_{A}: \rho:=\rho<1\right)$.

\section{Causality Test}

The Engle and Granger causality test to examine the causal relationship between the study variables was also adopted.

$$
\begin{aligned}
& \mathrm{Y}_{\mathrm{it}}=\alpha_{0}+\sum_{i=1}^{m} i Y i-t+\sum_{i=0}^{m} \beta i X i-t+\varepsilon_{\mathrm{it} .} \\
& \mathrm{X}_{\mathrm{it}}=\alpha_{0}+\sum_{i=1 j}^{m} Y t-j+\sum_{i=0}^{m} \beta j X t-j+\varepsilon_{\mathrm{it}}
\end{aligned}
$$

The null hypothesis of the Granger causality test states that $X$ does not Granger causes $Y$ expressed as

$$
\mathrm{H}_{O}: \beta i=0, i=1,2,3,4,5 \ldots, n .
$$

$X$ Granger causes $Y$ if and only if Equation 9 is rejected. To determine whether $Y$ Granger causes $X$ using Equation 10 is expressed hypothetically as:

$$
\mathrm{H}_{O}: \beta j=0, j=1,2,3,4,5 \ldots, n .
$$

\section{Data Analysis and Results}

\section{Pre-Test}

The series mean, and median are shown in Figure 1. The standard deviation is a metric for determining dispersions or deviations from the mean. Skewness depicts the degree of distortion from the symmetrical bell curve or the normal distribution, kurtosis depicts the tail of the series and Jarque-Bera depicts normality. The Kurtosis equals (=3), the results Mesokurtic. The datasets are normally distributed.

\section{Cross-Sectional Reliance Test}

The cross-sectional reliance test is fundamental to the empirical analysis process as it decides the methods to be utilized to perform the unit root and co-integration tests (see Table 3 below).

Table 3. Pesaran's Residual Cross-Sectional Dependence Test Results.

\begin{tabular}{|c|c|c|}
\hline Test & Statistic & Prob. \\
\hline Pesaran CD & 0.216888 & 0.8283 \\
\hline
\end{tabular}

Sources: Authors (2021)

Pesaran's test was employed to test for cross-sectional reliance in the series.

The null hypothesis of no cross-sectional independence could not be rejected at a conventional significance level.

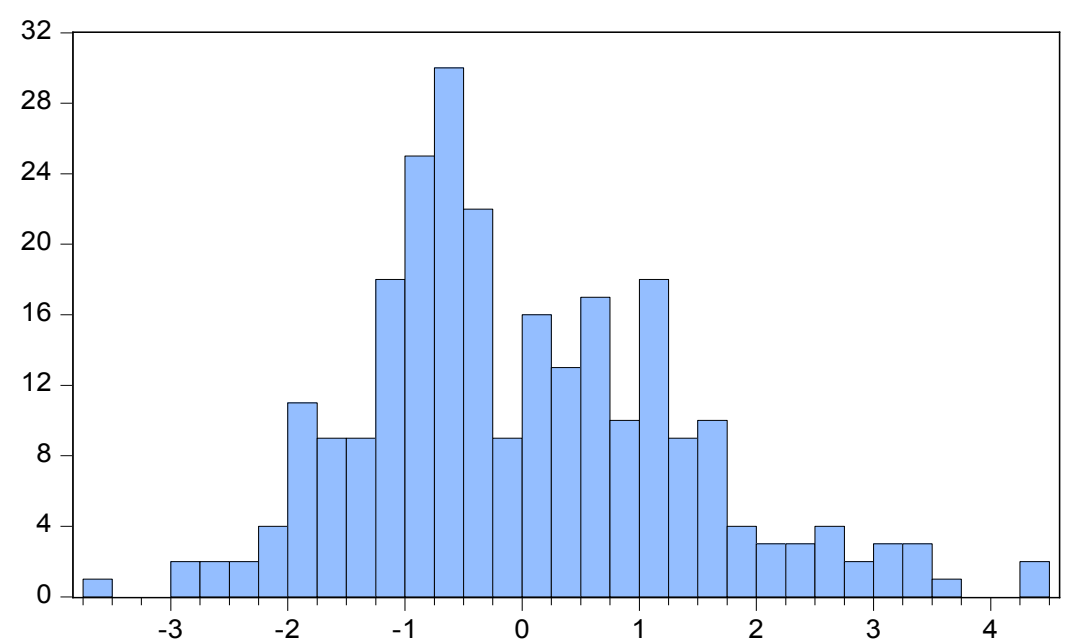

\begin{tabular}{ll}
\hline \multicolumn{2}{l}{ Series: Standardized Residuals } \\
Sample 19992020 \\
Observations 262 \\
Mean & -0.002183 \\
Median & -0.310145 \\
Maximum & 4.300701 \\
Minimum & -3.519032 \\
Std. Dev. & 1.376610 \\
Skewness & 0.545599 \\
Kurtosis & 3.232319 \\
& \\
Jarque-Bera & 13.58780 \\
Probability & 0.001121 \\
\hline
\end{tabular}

Sources: Authors (2021)

Figure 1. Descriptive Statistics 
Table 4. Panel Data Unit Root Test Results

\begin{tabular}{|c|c|c|c|c|c|c|}
\hline Order & Variables & LL \& C & IPS & ADF-Fisher & PP-Fisher & Remark \\
\hline \multirow{12}{*}{$\begin{array}{c}\text { First } \\
\text { Difference }\end{array}$} & InROE & -8.44468 & -10.6304 & 142.853 & 1225.21 & Stationary \\
\hline & & .0000 & .0000 & .0000 & .0000 & \\
\hline & InSIZE & -11.2419 & -10.3218 & 149.782 & 859.538 & Stationary \\
\hline & & .0000 & .0000 & .0000 & .0000 & \\
\hline & InTAN & -1.67522 & -8.44254 & 102.013 & 676.416 & Stationary \\
\hline & & .0000 & .0000 & .0000 & .0000 & \\
\hline & InEFF & -9.95316 & -9.66762 & 126.811 & 258.925 & Stationary \\
\hline & & .0000 & .0000 & .0000 & .0000 & \\
\hline & InCRA & -0.70346 & -3.27938 & -11.7588 & 153.958 & Stationary \\
\hline & & .0000 & .0005 & .0000 & .0000 & \\
\hline & InCRF & -15.6113 & -14.9889 & 181.951 & 700.797 & Stationary \\
\hline & & .0000 & .0000 & .0000 & .0000 & \\
\hline \multirow{12}{*}{ Levels } & InROE & -7.02218 & -3.48432 & 106.867 & 143.559 & Non-stationary \\
\hline & & .9845 & .7210 & .9821 & .6210 & \\
\hline & InSIZE & -5.71798 & -3.71753 & -4.57539 & 68.8459 & Non-stationary \\
\hline & & .8372 & .3692 & .8420 & .5821 & \\
\hline & InTAN & -12.7404 & -7.04034 & 293901 & 219.175 & Non-stationary \\
\hline & & .8931 & .9421 & .8746 & .5327 & \\
\hline & InEFF & 1.20313 & 1.38401 & 20.0257 & 37.9925 & Non-stationary \\
\hline & & .8855 & .9168 & .7903 & .0607 & \\
\hline & InCRA & -3.67363 & -1.73793 & -3.13465 & 53.5801 & Non-stationary \\
\hline & & .0203 & .0411 & .9034 & 0.3211 & \\
\hline & InCRF & -5.43894 & -2.58314 & -4.76112 & 81.1994 & Non-stationary \\
\hline & & .8103 & .2380 & .9872 & .0601 & \\
\hline
\end{tabular}

Source: Authors' Computation (2021)

Note. Figures in parenthesis denote probabilities. LL \& C $=$ Levin, Lin, and Chu; IPS $=\mathrm{Im}$, Pesaran and Shin W-stat; ADF-Fisher $=$ Augmented Dickey - Fuller-Fisher; PP-Fisher $=$ Phillips-Perron-Fisher; $\mathrm{CR}=$ Current Ratio; CFR = Cash Flow Ratio; SIZE = Size; GRO = Growth; EFF = Efficiency; TAN = Tangibility.

\section{Panel Data Unit Root Test}

Most time-series data employed in econometric researches are non-stationary, according to [43] validated by [44]. This means that they tend to either increase or decrease over time. The summarized unit test model of Levin, Lin, and the Chu, Im, Pesaran and Shin W-stat, Augmented Dickey-Fuller-Fisher; and Phillips-PerronFisher was used to test the stationarity properties of the variables.

The findings of the unit root test in table 4 above fail to reject the null hypothesis of non-stability at a level order $\mathrm{I}(0)$. The null hypothesis was rejected at the first difference I (1) since the variable gained stationarity.

The findings of the panel unit root demonstrate that the variables attend order of integration at I(1). To establish if the variables were co-integrated in the long run or not. Pedroni and Kao's tests for co-integration were adopted (see Table 5 \& 6).

\section{Panel Co-Integration Test Results}

Table 5. Pedroni's Residual Co-Integration Test Results.

\begin{tabular}{|c|c|c|}
\hline Statistics & Value & Prob. \\
\hline Panel v-Statistic & -2.321268 & 0.9899 \\
\hline Panel rho-Statistic & 2.456063 & 0.9930 \\
\hline Panel PP-Statistic & -3.740085 & $0.0001^{* *}$ \\
\hline Panel ADF-Statistic & -0.581316 & $0.0000^{* *}$ \\
\hline Group rho-Statistic & 3.820767 & 0.9999 \\
\hline Group PP-Statistic & -5.258344 & $0.0000^{* *}$ \\
\hline Group ADF-Statistic & -0.761967 & $0.0000^{* *}$ \\
\hline
\end{tabular}

Source: Authors' Computation (2021)

Note. $\mathrm{PP}=$ Phillips-Perron; ADF $=$ Augmented Dickey-Fuller.

$*$ Denotes rejection of the null hypothesis at a $1 \%$ significance level. 
Table 6. Kao's Residual Co-Integration Test Results.

\begin{tabular}{|c|c|c|}
\hline Test & t-Statistic & Prob. \\
\hline ADF & -4.579485 & $0.0000^{* *}$ \\
\hline Residual variance & 2.392303 & \\
\hline HAC variance & 1.236813 & \\
\hline
\end{tabular}

Source: Authors' Computation (2021)

The null hypothesis of no co-integration among the variables of Pedroni's test statistics reported in Table 5, was rejected at the conventional significance levels. The Kao's test results display in Table 6 also confirm the conclusion of Pedroni's test statistics at a p-value of (.0000).

\section{Model Determination and Estimation}

The Durbin-Wu-Hausman test was adopted to determine the best fit model for estimation.

Table 7. Hausman Test Results

\begin{tabular}{|c|c|c|c|c|}
\hline \multicolumn{2}{|c|}{ Test Summary } & $\chi^{2}$ Statistic & $\chi^{2}$. d.f. & Prob. \\
\hline Cross-section random & 1.670103 & 5 & .8926 \\
\hline \multicolumn{5}{|c|}{ Cross-section random effects test comparisons: } \\
\hline Variable & Fixed & Random & Var(Diff.) & Prob. \\
\hline InCFR & -0.016980 & -0.012019 & 0.000270 & 0.7628 \\
\hline InCRA & 0.085744 & 0.107668 & 0.000457 & 0.3050 \\
\hline InEFF & 0.007319 & -0.007381 & 0.000367 & 0.4431 \\
\hline InSIZE & 0.068472 & 0.079623 & 0.000927 & 0.7141 \\
\hline InTAN & 0.041041 & 0.051831 & 0.000310 & 0.5403 \\
\hline
\end{tabular}

Source: Authors' Computation (2021)

From Table 7, the results of the specification test showed a $\chi 2$ of 1.670103, and a P-Value of .8926. The results are largely statistically non-significant at the chosen alpha $(\alpha)$ levels. The fixed-effects model is rejected in favor of the random-effects model.

\section{Test of Hypothesis}

Hypothesis 1: There is no significant relationship between cash liquidity and firms' financial performance in the industrial sector in Nigeria.

Table 8. Estimated Results of the Parameter Model with Random Effects

\begin{tabular}{|c|c|c|c|c|}
\hline Variable & $\begin{array}{c}\text { Coefficient } \\
(\boldsymbol{\beta})\end{array}$ & $\begin{array}{c}\text { Std. } \\
\text { Error }\end{array}$ & t-Statistic & Prob. \\
\hline C & -1.243560 & 0.170071 & -7.311995 & 0.0000 \\
\hline InCFR & -0.016980 & 0.063692 & -0.266603 & 0.7900 \\
\hline InCRA & 0.085744 & 0.058957 & 1.454344 & 0.0000 \\
\hline InEFF & 0.007319 & 0.062384 & 0.117317 & 0.9067 \\
\hline InSIZE & 0.068472 & 0.080580 & 0.849741 & 0.3963 \\
\hline InTAN & 0.041041 & 0.025908 & 1.584140 & 0.1145 \\
\hline & 0 Other Parameter Model & 2.550 \\
\hline R-squared & 0.229 & \multicolumn{5}{|c|}{ Durbin-Watson stat } & 0.000 \\
\hline $\begin{array}{c}\text { Adjusted } \\
\text { R-squared }\end{array}$ & 0.175 & \multicolumn{5}{|l}{ Prob(F-statistic) } & \\
\hline F-statistic & 4.277 & & \\
\hline
\end{tabular}

Source: Authors' Computation (2021)
The results in (Table 8) revealed a negative and non-significant tie between $\operatorname{lnCFR}$ and $\operatorname{lnROE}(\beta=$ $-016980, p=.7900)$. As a result, a unit change in the firm's lnCFR has a negligible effect on the firms' financial performance. The findings of [29, 30, 45] among others confirm the result of this study that liquidity has a negligible impact on the firm's viability. Similarly, InCRA show a positive and significant relationship with InROE $(\beta=.085744, p=.0000)$. As a result, a unit increase in InCRA increases InROE by (.085744). The finding of $[16,25,22,23]$ collaborates our findings.

The result is consistent with the study's prior expectation $\left(\beta_{2}>0\right)$. The null hypothesis of no nexus between cash liquidity and firms' financial performance in the industrial sector in Nigeria is rejected. The firm size (lnSIZE) has a positive and non-significant influence on $\operatorname{lnROE}(\beta=.068472, p=.3963)$. Financial prowess of the firm is positively influenced by a unit increase in lnSIZE.

This finding was in line with [46] in Sri Lanka. The study also revealed that $\operatorname{lnEFF}$ has a non-significant beneficial impact on the firms' $\operatorname{lnROE}(\beta=.007319, p$ $=.9067)$. Changes in lnEFF do not affect the firms' lnROE. InTAN had a non-significant positive effect on $\operatorname{lnROE}(\beta=.041041, p=.1145)$. The increase has a non-significant impact on the firms' lnROE. [47] collaborated the findings of this study in 13 insurance firms in India.

\section{Other Parameters}

The $R^{2}$ value of .229 accounts for only $2.29 \%$ of the variances in lnROE, while $99.71 \%(100-2.29)$ of the variances was explained by other inherent variabilities. The F-stat of (4.277) and the p-value of (.000) show that the overall $R^{2}$ value was statistically significant for a meaningful analysis.

The Durbin Watson Statistics of (2.550) rules out all possible suspicion of first-order positive autocorrelation.

\section{Granger Causality Test Results}

The Engle and Granger (1987) test for causality was employed to determine the directional causality between lnCRA, lnCFR, lnSIZE, lnEFF, lnTAN, and lnROE.

\section{Test of Hypothesis}

Hypothesis 2: There is a statistically significant causal relationship between cash liquidity and firms' financial performance in the industrial sector in Nigeria.

The causal nexus reported in Table 9 shows the presence of a bidirectional tie between $\operatorname{lnCFR}$, InCRA, and $\ln R O E$. Thus, $\operatorname{lnCFR}$ and $\operatorname{lnROE}$ significantly cause each other. The results are further sustained by $[48,49$, 50,51]. A non-causal relationship between $\operatorname{lnTAN}, \operatorname{lnSIZE}$, $\operatorname{lnEFF}$, and $\operatorname{lnROE}$ was also observed. The findings of [52, $53,54,55]$ validate the finding of this research. [56] in India and [57] also validate the finding of this research. 
Table 9. Granger Causality Test Results

\begin{tabular}{|c|c|c|c|}
\hline Null Hypothesis: & Obs & F-Statistic & Prob. \\
\hline $\begin{array}{l}\text { lnCFR does not Granger Cause } \\
\text { lnROE }\end{array}$ & 220 & 4.285 & $.751^{* *}$ \\
\hline \multicolumn{2}{|c|}{$\operatorname{lnROE}$ does not Granger Cause lnCFR } & 3.836 & $.434 * *$ \\
\hline $\begin{array}{l}\text { lnCRA does not Granger } \\
\text { Cause lnROE }\end{array}$ & 218 & 2.045 & $.131^{* *}$ \\
\hline \multicolumn{2}{|c|}{$\operatorname{lnROE}$ does not Granger Cause lnCRA } & 3.359 & $.698^{* *}$ \\
\hline $\begin{array}{l}\operatorname{lnEFF} \text { does not Granger Cause } \\
\operatorname{lnROE}\end{array}$ & 234 & 0.543 & .581 \\
\hline \multicolumn{2}{|c|}{ lnROE does not Granger Cause lnEFF } & 0.900 & .408 \\
\hline $\begin{array}{l}\ln \text { lnIZE does not Granger } \\
\text { Cause } \operatorname{lnROE}\end{array}$ & 234 & 0.229 & .795 \\
\hline \multicolumn{2}{|c|}{ lnROE does not Granger Cause lnSIZE } & 0.226 & .797 \\
\hline $\begin{array}{l}\text { lnTAN does not Granger } \\
\text { Cause lnROE }\end{array}$ & 234 & 2.151 & .118 \\
\hline $\begin{array}{l}\operatorname{lnTAN} \text { does not } \text { Granger } \\
\text { Cause } \operatorname{lnEFF}\end{array}$ & 260 & 2.205 & .112 \\
\hline
\end{tabular}

Source: Authors' Computation (2021)

\section{Conclusions}

The cash flow management performance of quoted industrial firm nexus in Nigeria was explored in this paper. Liquidity proxy by current ratio positively and non-significantly impact on InROE of Nigerian firms. The alternative hypothesis was accepted and the null hypothesis overridden. Current cash flow proxy by liquidity has a negatively and non-significant influences on ROE. Similarly, the control variables of firm size, efficiency, and tangibility have a trivial effect on the ROE. The causal nexus according to the result revealed a bidirectional causal link between the current ratio, cash flow ratio, and ROE. A non-causal nexus was observed among the control variables. Based on the findings the following recommendations are made: resourceful liquidity management ensures the survival and development of the firm as a going concern. To achieve the desired optimal liquidity level, first must take a holistic approach to follow the NSE requirement. Firms must realize a balance between liquidity and profitability. Effective internal control mechanisms have a beneficial impact on the firm's InROE. To improve their profitability, liquidity, and competitive advantage prowess over competitive firms. A firm must grow in terms of customer base, net assets, sales volume, and market share.

\section{REFERENCES}

[1] Kimondo, C. N., Irungu, M., Obanda, M.. The impact of liquidity on the financial performance of the nonfinancial firms quoted on the Nairobi Securities Exchange. Research Journals Journal of Accounting, 4(2), 1-12. (2016)

[2] Orshi, T. S. Impact of liquidity management on the performance of listed food and beverages companies in Nigeria [Master's thesis, Federal University Dutsin-Ma]. (2016). https://doi.org/10.9790/487X-1821167
176

[3] Akenga, G.. Effect of liquidity on the financial performance of firms listed at the Nairobi Securities Exchange, Kenya. International Journal of Science and Research, 6(7), 279285. (2017)

[4] Alshatti, A. S. Effect of liquidity management on profitability of Jordanian commercial banks. International Journal of Business and Management, 10(1), 62-71. (2015)

[5] Ogbeide, Akanji, Relationship between Cash-flow and Financial Performance of Insurance Companies: Evidence from a Developing Economy. Review of International Comparative Management 18 (2) pp 148-157. (2017). DOI: 18.2019/idosi.ricm.2013.148.2.18620

[6] Akumu, O. C. Effect of free cash flow on the profitability of firms listed on the Nairobi securities exchange. African Development Review, 15(1), 35-49. (2017).

[7] Mbula, K., J., Memba, F, S., Njeru, A., Effect of Inventory Management on Financial Performance of Firms Funded by Government Venture Capital in Kenya. European Journal of Business and Management. 8,(5), (2016).

[8] Kajananthan, R., N., capital structure and firm performance. A study on Sri Lankan-listed manufacturing companies. Merit Research Journal of Business and Management 1(2) 037-044., (2013) https://ssrn.com/abstract=2379370

[9] Bhutto, N, A., Abbas, G., Rehman, M, Shah, M. Relationship of Cash Conversion Cycle with Firm Size, Working Capital Approaches and Firm's Profitability: A Case of Pakistani Industries. Pakistani Journal of Engineering Technology. Science. 1 (2), 45-64 (2011).

[10] Nwaiwu, N, J and Oluka, N, O., IFRS: Cash flow Accounting and Financial Performance of Quoted Companies in Nigeria. International Journal of Innovative Finance and Economics Research 5(4): pp 116-127. (2017)

[11] Nwakaego, D. A., Ikechukwu, O. Ifunanya, L. C. Effect of Cashflow Statement on company's performance of food and beverages companies in Nigeria. World Applied Sciences Journal, 33(12), 1852-1857. (2015). DOI: 10.5829/idosi.wa sj.2015.33.12.15630.

[12] Akinleye, G, T., Olarewaju, O, O. Credit Management and Profitability Growth in Nigerian Manufacturing Firms. OECONOMICA 15 (2) PP 445-456. (2019).

[13] Raykov, E. The liquidity-profitability trade-off in Bulgaria in terms of the changed financial management functions during the crisis. Management, 22(1), 135-156. (2017)

[14] Abubakar, A., Sulaiman, I., Haruna, U. Effect of firm's characteristics on the financial performance of listed insurance companies in Nigeria. African Journal of History and Archaeology, 3(1), 1-9. (2018).

[15] Ejike, S. I., Agha, N. C. Impact of operating liquidity on the profitability of pharmaceutical firms in Nigeria. International Journal of Academic Research in Accounting, Finance and Management Sciences, 8(3), 73-82. (2018).

[16] Mulyana, A., Zuraida, M. S. The influence of liquidity, profitability, and leverage on profit management and its impact on company value in manufacturing company listed on Indonesia Stock Exchange. International Journal of Managerial Studies and Research, 6(1), 8-14. (2018). HTTPS ://doi.org/10.1016/ S2212 -5671(15)01299-X

[17] Mohd, Y., Asif, P. Impact of liquidity, solvency, and 
efficiency on the profitability of Steel Authority of India Limited. International Journal of Research in Management, Economics, and Commerce, 6(9), 25-31. (2018)

[18] Saluja, P., Kumar, P., Liquidity and profitability tradeoff: A study on Airtel Bharti limited. International Journal of Advanced Research in Management and Social Sciences, 1(3),77-84 (2012).

[19] Jensen, M.C., Agency costs of free cash flow, corporate finance, and takeovers. The American Economic Review, 76(2), 323-329. (1986)

[20] Richards, V. D., Laughlin, E. J. A cash conversion cycle approach to liquidity analysis. Finance Manager, 9, 32-38. (1980)

[21] Cagle, C. S., Campbell, S. N., Jones, K. T. Analyzing liquidity using the cash conversion cycle.nhttp://journalofaccountancy. (2013) com/issues/2013 /may/20126764.html

[22] Kanga, O. S., Achoki, G. Liquidity and financial performance in agricultural firms listed in the Nairobi Securities Exchange in Kenya. International Journal of Business and Social Science, 7(7), 57-65. (2017).http://international Journal of Business and Social Science. com/issues/2013/may/20126764.html

[23] Ali, M., Bilal, M. E. Determinants of financial performance in the industrial firms: Evidence from Jordan. Asian Journal of Agricultural Extension, Economics \& Sociology,22(1), 1-10. (2018).

[24] Kimondo, C. N., Irungu, M., Obanda, M. (2016). The impact of liquidity on the financial performance of the nonfinancial firms quoted on the Nairobi Securities Exchange. Research Journals Journal of Accounting, 4(2), 1-12. (2016).

[25] Ali, M., Mahmoud, A., Fadi, A., Mohammad, O. Factors affecting the corporate performance: Panel data analysis for listed firms in Jordan. Academy of Accounting and Financial Studies Journal, 22(6), 1-10. (2018).

[26] Kung'u, N. J. Effect of liquidity management practices on the profitability of manufacturing industry in Kenya. IOSR Journal of Economics and Finance (IOSR-JEF), 8(1), 8489. (2017).

[27] Mohammed, M. Yusheng, K. (2019a). The effect of liquidity and capital structure on the financial performance of firms listed on the Ghana Alternative Market (GAX) International Journal of Research in Economics and Social Sciences, 8(2), 74-92. (2019a)

[28] Jepkemoi, E. Determinants of bank's profitability in Kenya [Master's thesis, University of Nairobi]. http://erepo.usiu. ac.ke/11732/3635. (2017).

[29] Batchimeg, B. Financial performance determinants of organizations: The case of Mongolian companies. Journal of Competitiveness, 9(3), 22-33. (2017)

[30] Ashutosh, G., Gurpreet, R. Financial performance of sugar mills in Punjab: A comparative study. Indian Journal of Accounting, 50(1), 87-96. (2018)

[31] Pordea, D, David, D, Mates. Impact of Operating Cash Flow and Current Ratio on The Profitability in Construction Industry. 2020 - 30(1) Economics Series. pp 22 - 32 (2020). DOI: $10.2478 /$ sues-2020-0002.

[32] Eton, M., Uwonda, G., Mwosi, F., Ogwel, B, P., Obote, D.,
Cash Management and Financial Performance of Business Firms in Northern Uganda a Case of Lira District. The International Journal of Business Management and Technology, 3 (4) PP 2581-3889 (2019).

[33] Ejike, S. I. Agha, N. C. Impact of operating liquidity on the profitability of pharmaceutical firms in Nigeria. International Journal of Academic Research in Accounting, Finance and Management Sciences, 8(3), 73-82. (2018).

[34] Ogbonnaya, A. K., Ekwe, M. C. Uzoma, I. J. Relationship of cash flow ratios and financial performance of listed banks in emerging economies - Nigeria example. European Journal of Accounting, Auditing and Finance Research, 4(4), 89-97. (2016)

[35] Augustine, I, N., Jacob, I, A. Cash Management and Performance of Listed Firms in Nigeria. Journal of Economics, Management, and Trade. 18(1): pp 1-13, 2017. (2017). https://doi.org/18.1.113/jemt2017.

[36] Jawed, M. S., Kotha, K. K. Stock liquidity and firm value: Evidence from a policy experiment in India. International Review of Finance, 20, 215-224.https://doi.org/10.1111/irfi .12200

[37] Osadune, R., Ibenta, S. Evaluation of the financial performance of deposit money banks in Nigeria (2001-2014). IIARD International Journal of Banking and Finance Research, 4(2), 23-50. (2018) http://hdl.iiard/42/23350120183

[38] Maina, S. N. The relationship between liquidity and the profitability of commercial banks in Kenya [Master's thesis, University of Nairobi]. (2017) http://hdl.handle.net/11295/1 03313

[39] Dabiri, A. M., Yusof, R. M., \& Wahab, N. A. Profitability and liquidity of Islamic banks in the United Kingdom. Asian Journal of Multidisciplinary Studies, 5(4), pp 66-71. (2017).

[40] Anowar, Z. Capital structure, and profitability of Bangladeshi firms: A causal investigation. Universal Journal of Accounting and Finance, 4(4), pp 130-135. (2016). https://doi.org/130.135.2016

[41] Pesaran, M. H. General diagnostic tests for cross-section dependence in panels. 9 (5) pp 20-34 (2004) https://doi.org/10.17863/CAM.5113

[42] Kao, C. D. Spurious regression and residual-based tests for cointegration in panel data. Journal of Econometrics, 90, 144. (1999)

[43] Engle, R. F., \& Granger, C. W. J. Co-integration and error correction: Representation, estimation, and testing. Econometrica, 55(2), 251-276. (1987)

[44] Hegwood, N., Papell, D. H. Are real GDP levels trend, difference, or regime-wise trend stationary? Evidence from panel data tests incorporating structural change. Southern Economic Journal, 74(1), pp 104-113. (2007) DOI: 74.11035/suel.2007.01202007.

[45] Asen, Nwude, Idamoyibo, Ufodiama, Udo., Effect of Capital Structure on Firms Performance in Nigeria," Universal Journal of Accounting and Finance, Vol. 9, No. 1, pp. 15 23, 2021. (2021). DOI: 10.13189/ujaf.2021.090102.

[46] Sivathaasan, N., Tharanika, R., Sinthuja, M. Hanitha, V. Factors determining profitability: A study of selected manufacturing companies listed on Colombo Stock Exchange in Sri Lanka. European Journal of Business and 
Management, 5(27). pp 99-107.(2013) DOI: 10.527/ejbm2 013.099107.

[47] Nikhil, B. D., Kingshuk, A., Mihir, R. B. Factors determining the financial performance of life insurance companies of India-An empirical study. EPRA International Journal of Economic and Business Review, 3(8), 42-47. (2015). DOI: 3.2.2/37/EPRAr.2051.042047.

[48] Anowar, Z. (2016). Capital structure and profitability of Bangladeshi firms: A causal investigation. Universal Journal of Accounting and Finance, 4(4), 130-135. (2016). DOI: 6.4.22/37/ijblr.2081.022037.

[49] Reis, S. G., Aydin, N. Causality relationship between stock liquidity and financial performance: An example of Borsa Istanbul. Gaziantep University Journal of Social Science, 13(3), 607-617. (2014).

[50] Nyamiobo, J. K., Willy, M., Walter, B. O., Tobias, O. Effect of firm characteristics on the financial performance of listed firms in Nairobi Securities Exchange. International Journal of Business and Law Research, 6(4), 22-37.DOI: 6.4.22/37/ijblr.2081.022037

[51] Swagatika, N., Ajaya, K. P. The determinants of corporate profitability: An investigation of Indian manufacturing firms. International Journal of Emerging Markets, 13(1), pp 66-86. (2018).

[52] Avdalović, S. M. Impact of firm-specific factors on profitability of industrial grinding companies. Economics of Agriculture, 2, pp 493-501. (2018) https://doi.org/10.5937/ ekoPolj1802493M

[53] Odusanya, I. A., Yinusa, O. G., Ilo, B. M. Determinants of firm profitability in Nigeria: Evidence from dynamic panel models. SPOUDAI Journal of Economics and Business, 68(1), pp 43-58. (2018).https://doi.org/68.1/jeb14358M
[54] Gichuhi, N. L. (2016). The effect of capital structure on profitability of firms listed at the Nairobi Securities Exchange [Master's thesis, University of Nairobi]. (2016) http://hdl.handle.net/11295/100254

[55] Mohammed, M. K., Ahmed, B. B., \& Mohammed, A. (2016). Effect of capital structure on performance of listed consumer goods companies in Nigeria. Research Journal of Accounting and Finance, 7(8), pp 211-219 (2016). DOI: 07.081/rjaf.2016.211.219

[56] Navleen, K. Jasmindeep, K. Determinants of profitability of automobile industry in India. Journal of Commerce \& Accounting Research, 5(3), pp 32-39 (2016).

[57] Demis, H. Macroeconomic and firm-specific determinants of profitability of insurance industry in Ethiopia. Global Journal of Management and Business Research and Finance, 16(7), pp 27-36. (2016) https://doi.org/10.27-36/g jmbrf. 122016

[58] Boubker Mouline, Hicham Sadok (2021). Corporate Cash Holdings and Agency Conflicts: Evidence from Moroccan Developing Market. Universal Journal of Accounting and Finance, 9(1), 24 - 32. DOI: 10.13189/ujaf.2021.090103.

[59] Asen Ayange, Nwude Chuke Emmanuel, Idamoyibo Hwerien Rosemary, Ufodiama Clifford Ndudi, Udo Emmanuel Samuel (2021). Effect of Capital Structure on Firms Performance in Nigeria. Universal Journal of Accounting and Finance, 9(1), 15 - 23. DOI: 10.13189/ujaf. 2021.090102

[60] Udo Emmanuel Samuel, Idamoyibo Hwerien Rosemary, Victor Inim, Akpan Jack Ededem, Victor Ndubuaku, (2021). Energy Consumption and Sectorial Value Addition on Economic Growth in Nigeria. Universal Journal of Accounting and Finance, 9(1), 74 - 85. DOI: 10.13189/ujaf.2021.090108. 